\title{
Investigation of Antibacterial Activity of Crude Extracts from Marine Snails and Bivalves in the Southern Coast of Vietnam
}

\author{
Pham Xuan Ky*, Pham Thi Mien, Le Ho Khanh Hy, Dao Viet Ha, Nguyen Phuong Anh, \\ Doan Thi Thiet, Phan Bao Vy, Ho Van The*
}

Institute of Oceanography, Vietnam Academy of Science and Technology (VAST), Nha Trang, Khanh Hoa, Vietnam

Email address:

phamkx@vnio.org.vn (P.X. Ky), hovantheio@gmail.com (Ho V. The)

${ }^{*}$ Corresponding author

To cite this article:

Pham Xuan Ky, Pham Thi Mien, Le Ho Khanh Hy, Dao Viet Ha, Nguyen Phuong Anh, Doan Thi Thiet, Phan Bao Vy, Ho Van The. Investigation of Antibacterial Activity of Crude Extracts from Marine Snails and Bivalves in the Southern Coast of Vietnam. American Journal of Biomedical and Life Sciences. Vol. 7, No. 1, 2019, pp. 10-15. doi: 10.11648/j.ajbls.20190701.13

Received: February 12, 2019; Accepted: March 14, 2019; Published: April 10, 2019

\begin{abstract}
The primary antibacterial activity of methanol and chloroform crude extracts from marine snails and bivalves was assessed by using the agar diffusion technique against four bacterial strains. Active methanol extracts were then characterized using TLC, SDS-PAGE and FTIR. Methanol extracts from 5 snail species and 8 extracts from 12 bivalve species possessed the ability to inhibit Bacillus subtilis. Methanol extracts from 3 snail species Tectus conus, Maninella alounia and Trochus maculatus inhibited Escheria coli and those from 4 snail species Cerithium chinatum, Maninella alounia, Tectus pyramis, Trochus maculatus and the bivalve species Pinna bicolor exhibited activity against Serratia marcescens. Chloroform extracts from 7 snail species and those from 7 bivalve species showed inhibition on Bacillus subtilis. Only chloroform extract from the bivalve Chama cf dunkeri was active on Salmonella typhimur and that from the snail Trochus maculatus and bivalve Lopha cristagali inhibited Escheria coli. TLC and FTIR analysis of active methanol extracts showed the presence of amino acids, peptides and proteins. SDS-PAGE of those extracts also revealed proteins with a molecular weight range between 10 and 28 $\mathrm{kDa}$. The obtained results indicate the potential antimicrobial compounds that could be explored in snail and bivalve in Vietnam.
\end{abstract}

Keywords: Snail, Bivalve, Crude Extracts, Antibacterial Activity, TLC, FTIR, SDS-PAGE

\section{Introduction}

Among marine invertebrates, mollusk is the second largest animal phylum, and account for $23 \%$ of the total species of marine organisms. They serve not only as a food source but also as a potential drug cabinet due to the richness in proteins and bioactive compounds. Many studies have reported the bioactivity of compounds from mollusc such as antioxidation and cytotoxicity, activities against inflammatory, microbes. For example, mussel Mytilus gallofwozvincialis plasma contained cytotoxic activity against both vertebrate (erythrocytes and mouse tumors) and protozoan cells [11] and myticin compounds possessing antimicrobial activity [17]. Sulfated beta-galactans from the clam Meretrix petechialis [1] and compounds from the clams Villorita cyprinoids, Meretrix casta and green mussel Perna viridis [7], magus cone Conus magus [23] exhibited inhibition on HIV-1. Antibaterial or antivirus compounds were also isolated from numerous mollusc such as the oysters Ostrea edulk, Crassostrea gigas [11], and Crassostrea virginica, the mussels Mytilus edulis, Geukensia demissa [2], and Perna canaliculus [24] and the white rock shell Dicathais orbita [5], the cone snails Conus betulinus and Conus inscriptus, the spiral Babylon Babylonia spirata [18, 19], the cuttlefish Sepia parshadi [21], squids Sepia sp., Loligo sp., snail Tibia insulaechorabcurta $[10,16]$ the sea hare Dolabella auricularia [26], sea slug Armina babai [22], the abalones Haliotis laevigata, H. rubra, and $H$. rufescens, snails 
Littorina littorea, Buccinulum corneum, Tegula gallina, Rapana venosa and Buccinum undatum), and hard clams Mercenaria mercenaria, Mya arenaria, Ruditapes philippinarum, cockle Cerastoderma edule, mussels Mytilus galloprovincialis and Crenomytilus grayanus), oysters Crassostrea virginica, C. gigas and Ostrea edulis (reviewed by Dang et al. 2015 [9]). The extracts from the green mussel Perna viridis and the Indian volute Melo melo also inhibited the replication of influenza virus, virus causing skin, mucosa, respiratory problems [7] and showed activity against some strains of bacteria and fungi $[6,13,14]$.

Vietnam has a long coastline and large territorial waters with the majority of mollusc species distributed along the country. The rich diversity of this animal assumes a great opportunity for exploring bioactive products. However, studies on bioactive compounds in mollusk are rare. In this investigation, we screened the antibacterial activity of organic extracts from snail and bivalve in the Southern waters of Vietnam to identify compounds of biomedical importance.

\section{Materials and Methods}

\subsection{Sampling}

Marine snails and bivalves were collected from different coastal habitats in the Southern coast of Vietnam in May 2017 by SCUBA diving during the joint investigation between Vietnam and Russia using the Akademik Oparin vessel. Sample photos were taken and identified by zoologists at the Institute of Oceanography, Vietnam. The marine snails and bivalves were cleaned with freshwater and deshelled, then the whole body tissues were collected and stored in liquid nitrogen. 7 snails and 12 bivalve species were used in this research.

\subsection{Extraction}

All homogenised tissues were extracted using methanol and chloroform solvents at a ratio of $1: 4(\mathrm{~g}: \mathrm{ml})$ and then stored at $4^{\circ} \mathrm{C}$ for $24 \mathrm{~h}$. The homogenate supernatants of each solvent were collected and filtered through Whatman No1. The tissues were extracted twice with the same solvent. The solvents from combined filtrates were evaporated completely. Dried crude extracts were used for the next experiments.

\subsection{Antibaterial Activity Test}

The antibacterial activity of the crude extracts was assessed by using the agar well diffusion technique on Mueller Hinton Agar (MHA-Himedia, India) according to Bauer et al (1996) [4]. Each of $100 \mathrm{mg}$ crude extract was dissolved into $1 \mathrm{ml}$ methanol (Merck). Antibacterial activity tests were performed on standard strains, including Bacillus subtilis (ATCC6633), Escherichia coli O157, Salmonella typhimurium (ATCC 6994) and Serratia marcescens PDL100 (ATCC BAA-632).

Bacteria were cultured in Marine agar medium, then inoculated into Marine Broth medium to grow up large amounts of bacteria. Standard strain broths were cultivated with a shaker at $120 \mathrm{rpm}$ for $24 \mathrm{~h}$ until cell density got McFarland standard at $10^{4} \mathrm{cfu} / \mathrm{ml}$. For each test, $100 \mu \mathrm{l}$ of bacterial broth was inoculated into petri dishes MHA and spread to form a lawn of individual cultures or strains. Add $30 \mu \mathrm{l}$ methanol dissolved extract into four wells on the inoculated MHA dishes. Methanol (Merck) was used as negative control well. Incubation of dishes was carried for 24h for B. subtilis, E. coli and S. typhimurium at $37^{\circ} \mathrm{C}$, and at $25^{\circ} \mathrm{C}$ for $S$. marcescens. The inhibition zone of each well was measured after incubation.

\subsection{Characterisation of Bioactive Extracts}

Methanol extracts showing activity against bacteria were characterized using thin-layer chromatography (TLC), Fourier transform infrared spectroscopy (FTIR) spectral analysis and SDS-polyacrylamide gel electrophoresis (SDS-PAGE).

TLC: The crude extracts were applied on 10x15 cm TLC silica gel 60 F254. To separate the components of the extracts, the solvent mixture of n-butanol: acetic acid: water (BAW) (5:1:4) was used. The sheets were sprayed with ninhydrin (1.5 $\mathrm{g}$ ninhydrin in $100 \mathrm{~mL}$ of ethanol) and was air dried and kept in an oven at $45^{\circ} \mathrm{C}$ for $5-10$ min to visualize the colored spots. The retardation factor $\left(\mathrm{R}_{\mathrm{f}}\right)$ was the distance traveled by the compound divided by the distance traveled by the solvent.

FTIR: Absorbance spectra of crystal methanol samples were recorded using Tensor 27- Bruker - Germany FTIR Spectrometer. The absorption of light intensity of the peak was calculated using the baseline method.

SDS-PAGE: SDS-PAGE was performed following the method of Laemmli (1970) [15]. The samples were dissolved in suitable urea buffer and the mixtures were incubated at room temperature overnight. The mixtures were centrifuged at $5000 \mathrm{rpm}$ for $5 \mathrm{~min}$ using microcentrifuge at room temperature in order to remove undissolved debris. The soluble samples were mixed at a ratio of $1: 1(\mathrm{v} / \mathrm{v})$ with the sample buffer $(0.5$ $\mathrm{M}$ Tris $\mathrm{HCl}, \mathrm{pH}$ 6.8, SDS $10 \%$ glycerol $100 \%$ and bromophenol blue) containing $2 \% \quad \beta$-mercaptoethanol. The mixtures were kept in boiling water for $5 \mathrm{~min}$. Samples were loaded onto polyacrylamide gels comprising $7.5 \%$ running gel and $4 \%$ stacking gel and subjected to electrophoresis at constant current of $10 \mathrm{~mA}$ in $30 \mathrm{~min}$ until samples and marker migrated from stacking gel to running gel, then increased current of $20 \mathrm{~mA}$ in 90 min using a mini protein unit (Bio Craft model BE-220 and Electrophoresis Power Supply EPS 601, Amersham Biosciences). After electrophoresis, the gels were stained with a solution containing Coomassie blue $0.25 \%$, methanol $40 \%$ and acid acetic $10 \%$. The used markers were Precision Plus ProteinTM Standards with molecular weight (MW) range of $10 \mathrm{kDa}$ to $180 \mathrm{kDa}$ (Bio-Rad Laboratories, Inc., Hercules, CA, USA).

\section{Results}

\subsection{Content (\%) of Crude Extracts}

The content of methanol extracts varied from 2.45 to $3.81 \%$ in snail and $1.68-3.52 \%$ in bivalve, and those of 
chloroform extracts from 0.18 to $0.72 \%$ in snail and $0.17-\quad 0.37 \%$ in bivalve (Table 1 ).

Table 1. Content (\%) of crude extracts from snails and bivalves.

\begin{tabular}{lll}
\hline Mollusc species & Content of methanol extract (\%) & Content of chloroform extract (\%) \\
\hline Snail & & \\
Cerithium chinatum & 3.26 & 0.72 \\
Tectus conus & 2.58 & 0.41 \\
Maninella alounia & 3.81 & 0.41 \\
Tectus pyramis & 2.98 & 0.25 \\
Trochus histrio & 2.67 & 0.18 \\
Trochus maculatus & 2.68 & 0.52 \\
Turbo chrysostomus & 2.45 & 0.31 \\
Bivalve & & \\
Lopha cristagali & 2.37 & 0.18 \\
Chama lazarus & 2.52 & 0.24 \\
Atrina sp & 2.96 & 0.27 \\
Chama cf dunkeri & 1.68 & 0.28 \\
Pinna bicolor & 2.39 & 0.17 \\
Tridacna crocea & 3.05 & 0.29 \\
Spondylus squamosus & 1.89 & 0.19 \\
Hyotissa spp & 2.59 & 0.32 \\
Barbatia foliata & 2.32 & 0.31 \\
Atrina vexillum & 2.73 & 0.30 \\
Hyotissa cf hyotis & 3.52 & 0.37 \\
Spondylus sp & 2.77 & 0.31 \\
\hline
\end{tabular}

\subsection{Antibacterial Activity}

Table 2. Diameter of inhibition zone (mean $\pm S D)(\mathrm{mm})$ of the antibacterial activity of methanol extracts from snails and bivalves.

\begin{tabular}{lllll}
\hline \multirow{2}{*}{ Mollusc species } & Inhibition zone $\mathbf{( m m )}$ & & & Serratia marcescens \\
\cline { 2 - 5 } Snail & Bacillus Subtilis & Salmonella typhimurium & & \\
Cerithium chinatum & $2.50 \pm 0.86$ & & 0 & $1.26 \pm 0.44$ \\
Tectus conus & $3.50 \pm 0.50$ & 0 & $2.26 \pm 0.44$ & 0 \\
Maninella alounia & $4.50 \pm 0.50$ & 0 & $2.50 \pm 0.86$ & $2.50 \pm 0.86$ \\
Tectus pyramis & $5.00 \pm 1.00$ & 0 & 0 & 0 \\
Trochus histrio & 0 & 0 & 0 & $2.00 \pm 0.0$ \\
Trochus maculatus & $1.00 \pm 0.0$ & 0 & $1.26 \pm 0.44$ & 0 \\
Turbo chrysostomus & 0 & 0 & 0 & 0 \\
Bivalve & & & & 0 \\
Lopha cristagali & 0 & 0 & 0 & 0 \\
Chama lazarus & $4.26 \pm 1.08$ & 0 & 0 & 0 \\
Atrina sp & $3.50 \pm 0.86$ & 0 & 0 & 0 \\
Chama cf dunkeri & $5.00 \pm 0.70$ & 0 & 0 & 0 \\
Pinna bicolor & $4.00 \pm 0.70$ & 0 & 0 & 0 \\
Tridacna crocea & $2.50 \pm 0.86$ & 0 & 0 & 0 \\
Spondylus squamosus & $3.50 \pm 0.86$ & 0 & 0 & 0 \\
Hyotissa spp & 0 & 0 & 0 & 0 \\
Barbatia foliata & 0 & 0 & 0 & 0 \\
Atrina vexillum & 0 & 0 & 0 & 0 \\
Hyotissa cf hyotis & $6.00 \pm 0.0$ & 0 & 0 & 0 \\
Spondylus sp & $1.76 \pm 0.44$ & 0 & 0 & 0 \\
\hline & & & & 0 \\
\end{tabular}

For methanol extracts, 5 among 7 of samples from snail (except 2 species Trochus histrio and Turbo chrysostomus) and 8 among 12 extracts from bivalve possessed the ability to inhibit Bacillus subtilis with inhibition zone from 1.0-5.0 mm and 2.50-6 mm, respectively. The extracts from 3 species of snail Tectus conus, Maninella alounia and Trochus maculatus inhibited Escheria coli with inhibition zones $2.26 \mathrm{~mm}, 2.50$ $\mathrm{mm}$ and $1.26 \mathrm{~mm}$, respectively. Extracts from Cerithium chinatum, Maninella alounia, Tectus pyramis, Trochus maculatus, and the bivalve Pinna bicolor exhibited activity against $S$. marcescens with inhibition zones recorded at 1.26 , 2.50, 2, $2 \mathrm{~mm}$, and $1.50 \mathrm{~mm}$. No extracts from snail and bivalve were active on $S$. typhimurium (Table 2). 
Table 3. Diameter of inhibition zone (mean $\pm S D)(\mathrm{mm})$ of the antibacterial activity of chloroform extracts from snails and bivalves.

\begin{tabular}{|c|c|c|c|c|}
\hline \multirow{2}{*}{ Mollusc species } & \multicolumn{4}{|c|}{ Inhibition zone (mm) } \\
\hline & Bacillus subtilis & Salmonella typhimurium & Escheria coli & Serratia marcescens \\
\hline \multicolumn{5}{|l|}{ Snail } \\
\hline Cerithium chinatum & $2.00 \pm 0.00$ & 0 & 0 & 0 \\
\hline Tectus conus & $5.26 \pm 0.44$ & 0 & 0 & 0 \\
\hline Maninella alounia & $2.50 \pm 0.86$ & 0 & 0 & 0 \\
\hline Tectus pyramis & $6.00 \pm 0.0$ & 0 & 0 & 0 \\
\hline Trochus histrio & $6.50 \pm 0.86$ & 0 & 0 & 0 \\
\hline Trochus maculatus & $1.50 \pm 0.50$ & 0 & $1.76 \pm 1.08$ & 0 \\
\hline Turbo chrysostomus & $4.00 \pm 0.00$ & 0 & 0 & 0 \\
\hline \multicolumn{5}{|l|}{ Bivalve } \\
\hline Lopha cristagali & $2.50 \pm 0.86$ & 0 & $2.26 \pm 0.44$ & 0 \\
\hline Chama lazarus & $3.26 \pm 0.82$ & 0 & 0 & 0 \\
\hline Atrina $s p$ & $3.26 \pm 1.08$ & 0 & 0 & 0 \\
\hline Chama cf dunkeri & 0 & $1.00 \pm 0.00$ & 0 & 0 \\
\hline \multicolumn{5}{|l|}{ Pinna bicolor } \\
\hline Tridacna crocea & $2.50 \pm 0.50$ & 0 & $2.26 \pm 0.44$ & 0 \\
\hline \multicolumn{5}{|l|}{ Spondylus squamosus } \\
\hline Hyotissa spp & $2.00 \pm 0.00$ & 0 & 0 & 0 \\
\hline Barbatia foliata & $3.26 \pm 0.82$ & 0 & 0 & 0 \\
\hline \multicolumn{5}{|l|}{ Atrina vexillum } \\
\hline Spondylus sp & $2.50 \pm 0.50$ & 0 & 0 & 0 \\
\hline
\end{tabular}

In chloroform extracts, the obtained results revealed that 7 extracts from 7 snail species and 7 among 12 extracts from bivalve (except Chama cf dunkeri, Pinna bicolor, Spondylus squamosus, Atrina vexillum, Hyotissa cf hyotis) showed inhibition on B. subtilis with inhibition zones $2.0-6.50 \mathrm{~mm}$ and 2.0-3.26 mm, respectively. Only extract from the bivalve Chama cf dunkeri inhibited $S$. typhimurium with inhibition zone $1.0 \mathrm{~mm}$. Extracts from snail Trochus maculatus and bivalve Lopha cristagali exhibited activity against $E$. coli with inhibition zones 1.76 and $2.26 \mathrm{~mm}$. All chloroform extracts from snail and bivalve were insensitive against $S$. marcescens (Table 3).

\subsection{Protein Pattern}

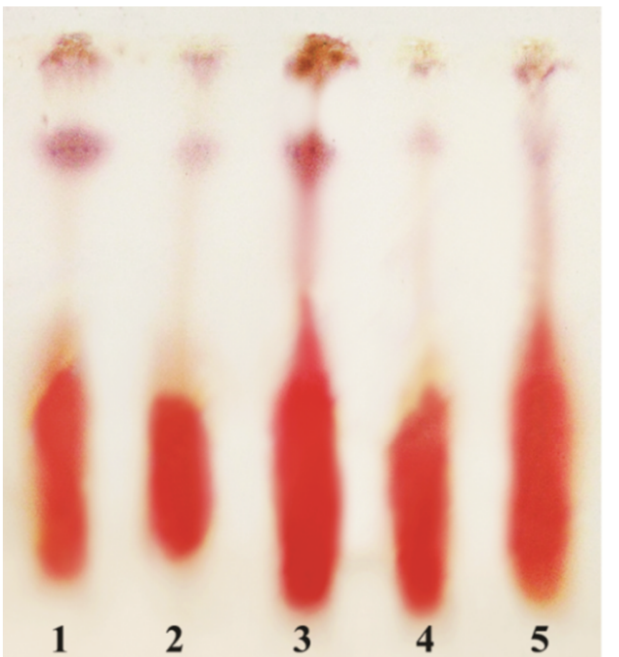

Figure 1. TLC profile of methanol extracts: 1. Cerithium chinatum; 2. Tectus conus; 3. Tectus pyramis; 4. Trochus maculatus; 5. Pinna bicolor.
The sheet showing purple to pink spots by TLC indicated the presence of amino acids and peptides in the active samples with $R_{\mathrm{f}}$ of 0.82 and 0.91 (Figure 1 ).

FTIR: The IR spectra of the methanol extracts revealed the characteristic peaks of proteins (data not shown) and Figure 2 shows the IR spectrum of the methanol extract from the representative species Trochus maculatus. The free $\mathrm{NH}$ stretching vibration appeared at $3413 \mathrm{~cm}^{-1}$ and the amide I vibration, absorbing at $1629 \mathrm{~cm}^{-1}$, arises mainly from the $\mathrm{C}=\mathrm{O}$ stretching vibration with minor contributions from the out-of-phase $\mathrm{CN}$ stretching vibration, the $\mathrm{CCN}$ deformation and the $\mathrm{NH}$ in-plane bend. N-deuteration converted the amide II mode to largely a C-N stretching vibration at 1490 $1460 \mathrm{~cm}^{-1}$ (named amide II mode). The amide III region (1200-1350 $\left.\mathrm{cm}^{-1}\right)$ is N-H in-plane bending coupled with C-N stretching and also includes $\mathrm{C}-\mathrm{H}$ and $\mathrm{N}-\mathrm{H}$ deformation vibrations. The absorbance at $527-601 \mathrm{~cm}^{-1}$ was the result of the vibration of out-of-plane $\mathrm{CO}$ bending [3].

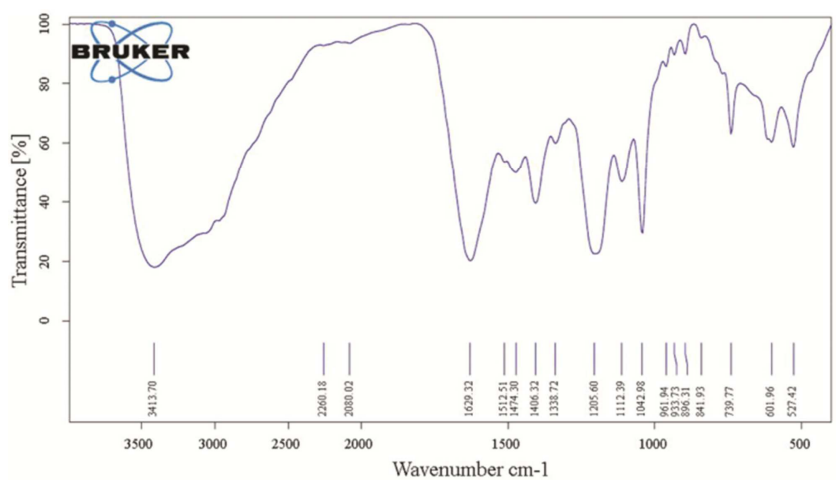

Figure 2. FTIR spectrum of the methanol extract of the representative species Trochus maculatus. 
SDS-PAGE analysis of methanol samples revealed the presence of proteins with MW range between 10-28 $\mathrm{kDa}$ (Figure 3).

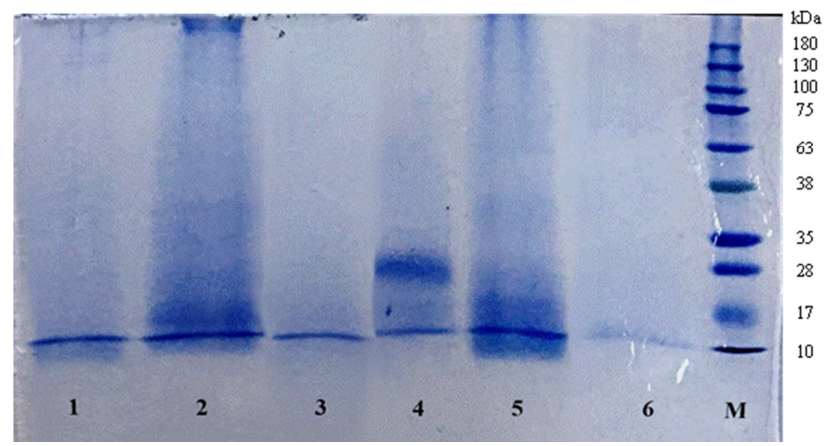

Figure 3. Protein pattern of methanol extracts determined by SDS-PAGE: 1. Maninella alounia; 2. Tectus conus; 3. Cerithium chinatum; 4. Tectus pyramis; 5. Trochus maculatus; 6. Pinna bicolor; M: Protein standard.

\section{Discussion}

In this research, the content of crude extracts varied depending on the type of extraction solvents. Indeed, from the same species, the methanol extraction produces more yield than that of chloroform. Methanol and chloroform extracts exhibited antibacterial activity against tested bacteria with varying degrees. Most methanol and chloroform extracts from the snail and bivalve possessed the ability against Grampositive Bacillus subtilis. This result is similar to Jayaseeli et al. (2001) [12], who reported that the extracts of four bivalve species showed significant activity against Bacillus subtilis and inhibition of few pathogenic bacteria. The number of methanol extracts possessing the ability against Gram-negative pathogenic bacteria is higher than those of chloroform extracts, the reason could be that methanol is much more polar and extract more hydrophilic compounds than chloroform. In the green mussel Perna viridis, the methanolic extract was more active and showed antibacterial activity at low concentrations, the study showed that the substance involved in producing the antibacterial effect could be a high polar compound [14]. Similar results were observed in Octopus dolfusii with inhibition of methanol extracts against Escherichia coli and Streptococcus pneumonia [21] and in the sea slug Armina babai with the crude methanol extracts displaying good activity on the selected pathogenic bacteria [22]. In our research, the antibacterial activity was observed against some pathogenic bacteria from crude methanol extracts, indicating that this solvent is suitable for the extraction of bioactive compounds in a mollusc.

On the other hand, in our investigation, the TLC and IR results demonstrated the presence of protein compounds. TLC indicated the presence of amino acids and peptides with $\mathrm{R}_{\mathrm{f}}$ of 0.82 and 0.91 and this result had the same $R_{\mathrm{f}}$ compared to the amino acids and peptides in the sea slug Armina babai [22]. In addition, the IR spectrum of crude methanol extract from the representative species confirms the existence of protein compounds with amide I, II, III vibrations.

On protein properties, SDS-PAGE analysis of methanol extracts active on bacteria revealed the proteins in the range of very low MW from 10 to $28 \mathrm{kDa}$. The result of Ramya et al. (2014) [22] showed the existence of peptide or amino acid with purple or violet by TLC and MW of proteins from 13-72 $\mathrm{kDa}$ by SDS-PAGE from bioactive antibacterial extracts in the sea slug Armina babai. Periyasamy et al. (2012b) [19] found MW of proteins in the active extract on bacteria from the spiral Babylon Babylonia spirata was distributed from 2-110 kDa. MW of antibacterial protein extracted from the gill of the green mussel Perna viridis was $9.7 \mathrm{kDa}$ [6], and that of methanol extract from the tissue of this species was $20-63 \mathrm{kDa}$ [16]. Analysis of the crude proteins from the clams Meretrix meretrix and Meretrix casta showed protein bands ranging from 45 to $261 \mathrm{kDa}$ [25]. More or less similar MW protein was also isolated from $14 \mathrm{kDa}$ and $29 \mathrm{kDa}$ in the clam Meretrix casta and the green mussel Perna viridis. Usually, snail and bivalve contain a variety of molecules which exhibit promising level of antibacterial activity. Small size proteins have been the proven to possess strong antioxidant, antimicrobial activity, therefore they could be potential drug source with great promise for the discovery of novel bioactive compounds instead of a plant. This study indicates the presence of potent antimicrobial compounds in marine snails and bivalves on the Southern coast of Vietnam. Several compounds from some bivalves in Cat $\mathrm{Ba}$, northern Vietnam also showed the antibacterial effect against 1-2 pathogenic bacteria strain and 1 compound inhibited MCF7 and HepG2 [20]. Other researches reported that marine mollusc is considered as a good source of bioactive metabolites possessing inflammatory, microbial, oxidant and cytotoxic activity [8].

\section{Conclusions}

The preliminary results obtained in the present study indicate that the whole body of some marine snail and bivalve species would be a potential source of antibacterial agents that could be explored and potentially developed in Vietnam. Isolation and structural elucidation of bioactive compounds from these marine molluscan extracts are needed to be carried out in further studies.

\section{Acknowledgements}

We are indebted to the captain and crew of the research vessel "Akademik Oparin", who were most helpful during all our shipboard operations. The authors are sincerely thankful to Mr. Hua Thai Tuyen, the Institute of Oceanography, Vietnam for identifying snail and bivalve species. The research is a part of the project No. VAST.HTQT.NGA. 15-02/16-17 supported by Vietnam Academy of Science and Technology.

\section{References}

[1] Amornrut C., Toida T., Imanari T., Woo E. R., Park H., Linhardt R., Wu S. J. and Kim Y. S. (1999). A new sulfated beta-galactan from clams with anti-HIV activity. Carbohydrate Research 321: 121-127. 
[2] Anderson R. S. and Beaven A. E. (2001). Antibacterial activities of oyster (Crassostrea virginica) mussel (Mytilus edulis and Geukensia demissa) plasma. Aquatic Living Resources 14: 343-49.

[3] Barth A. (2007). Infrared spectroscopy of proteins. Biochimica et Biophysica Acta (BBA) - Bioenergetics. 1767, pp. 1073-1101.

[4] Bauer A. W., Kirby W. M., Sherris J. C. and Turck M. (1996). Antibiotic susceptibility testing by a standardized single disk method. American Journal of Clinical Pathology 45: 493-496.

[5] Benkendorff K., Bremner J. B. and Davis A. R. (2001). Indole derivatives from the egg masses of Muricid molluscs. Molecules 6: 70-78.

[6] Chandran B., Rameshkumar G. and Ravichandran S. (2009). Antimicrobial activity from the gill extraction of Perna viridis (Linnaeus, 1758). Global Journal of Biochemistry and Biotechnology 4: 88-92.

[7] Chatterji A., Ansari Z. A., Ingole B. S., Bichurina M. A., Sovetova M. and Boikov Y. A. (2002). Indian marine bivalves: Potential source of antiviral drugs. Current Science 81: 1279-1282.

[8] Cimino G., Fontana A., Cutignano A. and Gavagnin M. (2004). Biosynthesis in opisthobranch molluscs: General outline in the light of recent use of stable isotopes. Phytochemistry Reviews 3: 285-307.

[9] Dang V. T., Kirsten B., Tim G. and Peter S. (2015). Marine snails and slugs: a great place to look for antiviral drugs. Journal of Virology 89: 8114-8118.

[10] Degiam Z. D. and Abas A. T. (2010). Antimicrobial activity of some crude marine Mollusca extracts against some human pathogenic bacteria. Thi-Qar Medical Journal 3: 142-147.

[11] Hubert F., Knaap W., Noël T. and Roch P. (1996). Cytotoxic and antibacterial properties of Mytilus gallofwozvincialis, Ostrea edulk and Crassostrea gigas (Bivalve molluses) hemolymph. Aquatic Living Resources 9: 115-124.

[12] Jayaseeli A. A., Anand P. and Murugan T. A. (2001). Antibacterial activity of four-bivalves from Gulf of Mannar. Phuket Mar. Biol. Cent. Spl. Pub. 25: 215-217.

[13] Kanagasabapathy S., Samuthirapandian R. and Kumaresan M. (2011). Preliminary studies for a new antibiotic from the marine mollusk Melo melo (Lightfoot, 1786). Asian Pacific Journal of Tropical Medicine 4: 310-314.

[14] Kiran N., Siddiqui G., Khan A. N., Ibrar K. and Tushar P. (2014). Extraction and screening of bioactive compounds with antimicrobial properties from selected species of mollusk and crustacean. Journal of Clinical \& Cellular Immunology. doi.org/10.4172/2155-9899.1000189.

[15] Laemmli U. K. (1970). Cleavage of structural proteins during the assembly of the head of bacteriophage. Nature $227: 680$ 685 .
[16] Madhu V. N., Sivaperumal P., Kamala K., Ambekar A. A. and Kulkarni B. G. (2014). Antibacterial and antioxidant activities of the tissue extract of Perna viridis Linnaeus, 1758 (mollusca: Bivalvia) from Versova coast, Mumbai. International Journal of Pharmacy and Pharmaceutical Sciences 6: 704-707.

[17] Mitta G., Hubert F., Noel T. and Roch P. (1999). Myticin, a novel cysteine-rich antimicrobial peptide isolated from haemocytes and plasma of the mussel Mytilus galloprovincialis. European Journal of Biochemistry 265: 7178.

[18] Periyasamy N., Arularasan S. and Gayathri S. (2012a). Antibacterial activity of the tissue extracts of Conus betulinus and Conus inscriptus Linnaeus, 1758 (Mollusca: Gastropoda) from Nagapattinam, Southeast coast of India. Asian Pacific Journal of Tropical Biomedicine 2: 914-919.

[19] Periyasamy N., Srinivasan M. and Balakrishnan S. (2012b). Antimicrobial activities of the tissue extracts of Babylonia spirata Linnaeus, 1758 (Mollusca: Gastropoda) from Thazhanguda, southeast coast of India. Asian Pacific Journal of Tropical Biomedicine 2: 36-40.

[20] Phan T. T. H. and Chau V. M. (2016). Study on cytotoxicity, antimicrobial activity and search for bioactive coumpounds from 10 mollusc species in Cat Ba island. VAST Project No. $04.08 / 14-15$

[21] Ramasamy P., Vino A. B., Saravanan R., Subhapradha N., Shanmugam V. and Shanmugam A. (2011). Screening of antimicrobial potential of polysaccharide from cuttle bone and methanolic extract from body tissue of Sepia prashadi Winkworth, 1936. Asian Pacific Journal of Tropical Biomedicine 1: 244-248.

[22] Ramya M. S., Sivasubramanian K., Ravichandran S. and Anbuchezhian R. (2014). Screening of antimicrobial compound from the sea slug Armina babai. Bangladesh Journal of Physiology and Pharmacology 9: 268-274.

[23] Schroeder C. I., Smythe M. L. and Lewis R. J. (2004). Development of small molecules that mimic the binding of omega-conotoxins at the N-type voltagegated calcium channel. Molecular Diversity 8: 127-134.

[24] Scotti P. D., Dearing S. C., Greenwood D. R. and Newcomb R. D. (2001). Pernin: a novel, self-aggregating haemolymph protein from the New Zealand greenlipped mussel, Perna canaliculus (Bivalvia: Mytilidae). Comparative Biochemistry \& Physiology 128: 767-79.

[25] Sumita S., Chatterji A. and Das P. (2009). Effect of different extraction procedures on antimicrobial activity of marine bivalves: a comparison. Pertanika Journal of Tropical Agricultural Science 32: 77-83.

[26] Vennila R., Kumar R. K., Kanchana S., Arumugam M. and Balasubramanian T. (2011). Investigation of antimicrobial and plasma coagulation property of some molluscan ink extracts: Gastropods and cephalopods. African Journal of Biochemistry Research 5: 14-21. 